\title{
NOVEL SANTALANE SESQUITERPENOIDS FROM THE STEM BARK OF DUGUETIA GLABRIUSCULA - ANNONACEAE
}

\author{
Núbia F. Gomes Pereira, Carlos Alexandre Carollo e Walmir Silva Garcez \\ Departamento de Química, Centro de Ciências Exatas e Tecnologias, Universidade Federal de Mato Grosso do Sul, CP 549, \\ 79070-900 Campo Grande - MS

\section{João Máximo de Siqueira*} \\ Departamento de Farmácia-Bioquímica, Centro de Ciências Biológicas e da Saúde, Universidade Federal de Mato Grosso do Sul, \\ CP 549, 79070-900 Campo Grande - MS
}

Recebido em 30/9/02; aceito em 16/12/02

\begin{abstract}
NOVEL SANTALANE SESQUITERPENOIDS FROM THE STEM BARK OF Duguetia glabriuscula - ANNONACEAE. Five novel santalane-type sesquiterpenes were isolated from the stem bark of Duguetia glabriuscula - Annonaceae. Their structures have been established on the basis of spectral data and chemical evidences $\left({ }^{1} \mathrm{H}\right.$ and ${ }^{13} \mathrm{C}$ NMR, HMQC, HMBC) as $(+)-\alpha$-santal10-en-9-ol (1), (+)- $\alpha$-santalan-10,11-epoxy-9-ol (2), $\alpha$-santal-11-en-9,10-diol (3), (+)- $\alpha$-santalan-9,10,11-triol (4), and (+)- $\alpha$ santalan-9,11-epoxy-10-ol (5). Polycarpol, a triterpenoid, was also obtained.
\end{abstract}

Keywords: Annonaceae; Duguetia glabriuscula; santalane sesquiterpenes.

\section{INTRODUCTION}

The Duguetia genus, of the Annonaceae family, comprises about 80 native species with predominance in the tropical Americas and a center of distribution in the Amazon basin and Guyana, although some of its representatives are found in the southern region of South America ${ }^{1}$. Few data are available on the use of this genus in folk medicine. On the popular use of Duguetia glabriuscula, particularly, which is a shrub native to the state of Mato Grosso do Sul, in southwestern Brazil, no data whatsoever could be found.

In our previous studies conducted by means of Artemia salina activity-guided fractionation of the chloroform fraction of the stem bark of this species, two oxoaporphine alkaloids were isolated, in addition to other compounds that were inactive ${ }^{2}$. The present investigation, in turn, led to the isolation, from the petroleum ether fraction of the same part of the plant, of the novel santalane sesquiterpenoids $\mathbf{1}, \mathbf{2}, \mathbf{3}, \mathbf{4}$, and $\mathbf{5}$, along with the triterpenoid polycarpol. The structures of all five sesquiterpenoids were established on the basis of NMR, by using a combination of ${ }^{1} \mathrm{H}$ and ${ }^{13} \mathrm{C}$ (including DEPT) data, together with 2D NMR (HMQC, HMBC, and $\left.{ }^{1} \mathrm{H}-{ }^{1} \mathrm{H}-\mathrm{COSY}\right)$ spectral data. Chemical evidences were used to determine the relative stereochemistry of compounds $\mathbf{2 , 3}$, and $\mathbf{4}$.

\section{RESULTS AND DISCUSSION}

The close resemblance of the ${ }^{1} \mathrm{H}$ and ${ }^{13} \mathrm{C}$ NMR spectra of $\mathbf{1}, \mathbf{2}, \mathbf{3}$, $\mathbf{4}$, and $\mathbf{5}$ to those of a tricyclene-type carbon skeleton made it possible to compare the compounds to each other (Tables 1 and 2) and to models described in the literature ${ }^{3,4}$. Because functionalization in each sesquiterpene only occurred in the side chain, the 2D NMR experiments $\left({ }^{1} \mathrm{H}-{ }^{1} \mathrm{H}-\mathrm{COSY}, \mathrm{HMQC}, \mathrm{HMBC}\right)$ provided support for the elucidation of this moiety.

The IR spectrum of compound $\mathbf{1}$ indicated the presence of one hydroxyl group $\left(3368 \mathrm{~cm}^{-1}\right)$ and two weak bands for a cyclopropane ring $\left(3050 \mathrm{~cm}^{-1}\right)$ and a trisubstituted olefin $\left(1674 \mathrm{~cm}^{-1}\right)$. The ${ }^{1} \mathrm{H}$ (Table

*e-mail: jmaximo@nin.ufms.br

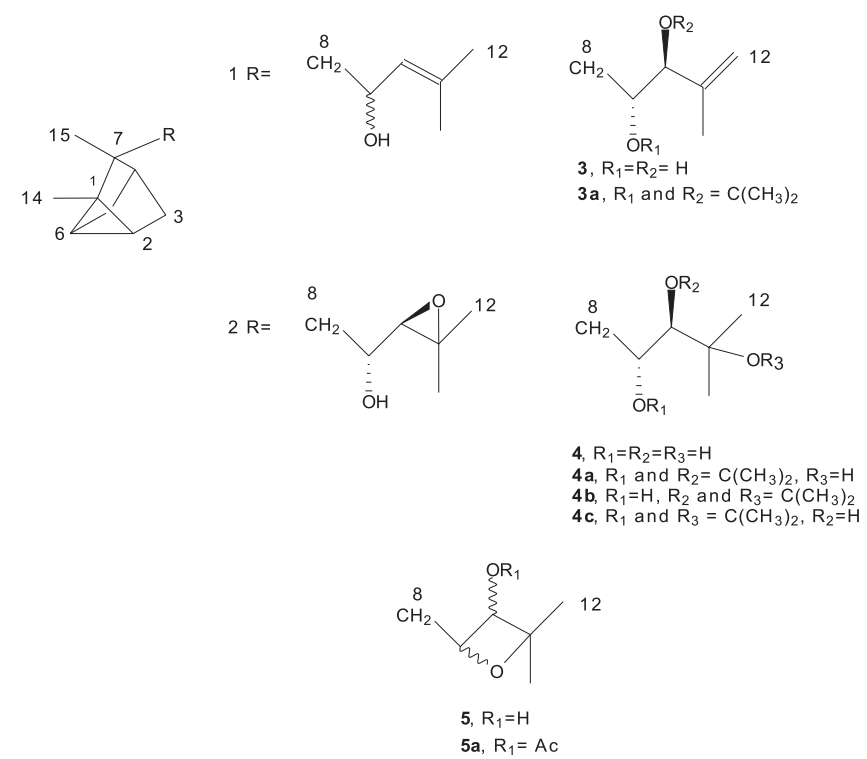

Figure 1. Santalane-type sesquiterpenes isolated from D. glabriuscula

1) and ${ }^{13} \mathrm{C}$ NMR (Table 2) spectra combined with an HMQC experiment displayed signals of an olefinic proton $\left[\delta_{\mathrm{H}} 5.19(1 \mathrm{H}, \mathrm{td})\right.$, $\left.\delta_{\mathrm{C}} 129.7\right]$, a proton attached to an oxygen carbon $\left[\delta_{\mathrm{H}} 4.45(1 \mathrm{H}, \mathrm{ddd})\right.$, $\left.\delta_{\mathrm{C}} 66.8\right]$, four methyl groups, of which two were methyl doublets $\left[\delta_{\mathrm{H}}\right.$ 1.68 and 1.69 ( $3 \mathrm{H}$ each, d), $\delta_{\mathrm{C}} 18.1$ and 25.8 , respectively], and two singlet methyls $\left[\delta_{\mathrm{H}} 0.97\right.$ and 0.83 ( $3 \mathrm{H}$ each, s), $\delta_{\mathrm{C}} 10.7,18.1$, respectively]. Moreover, two signal doublets were present, which could be characterized as a hydrogen of a cyclopropane ring $\left[\delta_{\mathrm{H}} 0.80\right.$ and $0.76(1 \mathrm{H}$ each, $\mathrm{d}), \delta_{\mathrm{C}} 19.5$ and 18.7 , respectively]. Of the carbons observed in the ${ }^{13} \mathrm{C}$ NMR (including DEPT) spectra of $\mathbf{1}$, three were quaternary (one of them olefinic), whereas three belonged to methylene groups, five to methine (one of them oxygen-bearing and one olefinic), and four to methyl (two of them as vinylic methyls) groups. Substance $\mathbf{1}$ showed in its HREIMS a molecular ion peak at 
$m / z, 220.1819[\mathrm{M}]^{+}(32 \%)$, which made it possible to propose the molecular formula $\mathrm{C}_{15} \mathrm{H}_{24} \mathrm{O}$. Another peak at $\mathrm{m} / z, 121(17 \%)$-an ion fragmentation typical of a tricyclene skeleton with loss of the side chain in santalane sesquiterpenoids-was also observed.

The IR spectrum of compound 2 revealed two main absorptions at $3443 \mathrm{~cm}^{-1}$ and $3050 \mathrm{~cm}^{-1}$, which were assignable to a hydroxyl group and a cyclopropane ring, respectively. Data from the ${ }^{1} \mathrm{H}$ and ${ }^{13} \mathrm{C}$ NMR spectra (including DEPT) and HMQC experiment were indicative of an epoxy group $\left[\delta_{\mathrm{H}} 2.64(1 \mathrm{H}, \mathrm{d}), \delta_{\mathrm{C}} 66.7\right.$, and a quaternary carbon at $\left.\delta_{\mathrm{C}} 59.4\right]$. In addition, a proton attached to an oxygenated carbon $\left[\delta_{\mathrm{H}}\right.$ $\left.3.65(1 \mathrm{H}, \mathrm{dd}), \delta_{\mathrm{C}} 68.4\right]$ and four singlet signals for methyl groups were observed $\left[\delta_{\mathrm{H}} 1.37,1.32,0.99\right.$, and 0.87 ( $3 \mathrm{H}$ each, s), and $\delta_{\mathrm{C}} 18.5$, 25.0, 10.6 and 17.7, respectively]. The molecular formula of 2 was determined as $\mathrm{C}_{15} \mathrm{H}_{24} \mathrm{O}_{2}$ by HREIMS, which showed a molecular ion peak at $m / z, 236.1707(6 \%)$ and a fragment ion peak at $\mathrm{m} / \mathrm{z}, 121$ (100\%).

The IR spectrum of $\mathbf{3}$ showed absorptions at $3410 \mathrm{~cm}^{-1}$ and at $3051 \mathrm{~cm}^{-1}$ corresponding to a hydroxyl group and a cyclopropane ring, respectively. The ${ }^{1} \mathrm{H}$ and ${ }^{13} \mathrm{C}$ NMR (including DEPT) spectra combined with the HMQC experiment revealed olefinic signals $\left[\delta_{\mathrm{H}}\right.$ 5.03 and 4.97 (1H each, s), $\delta_{C} 112.8$ ], and a quaternary olefinic carbon $\left[\delta_{C} 144.3\right]$ and two signals from protons of methine carbinolic carbons [ $\delta_{\mathrm{H}} 4.01(1 \mathrm{H}, \mathrm{s})$ and $3.81(1 \mathrm{H}, \mathrm{dd}), \delta_{\mathrm{C}} 79.4$ and 70.7 , respectively]. However, only three signals for methyl groups were observed $\left[\delta_{\mathrm{H}}\right.$ $1.74,0.96$ and 0.83 ( $3 \mathrm{H}$ each, s), $\delta_{\mathrm{C}} 19.1,10.7$ and 17.6 , respectively] and two for cyclopropane rings $\left[\delta_{\mathrm{H}} 0.83\right.$ and $0.78(1 \mathrm{H}, \mathrm{dd}), \delta_{\mathrm{C}} 19.4$ and 18.4, respectively]. On their turn, the ${ }^{13} \mathrm{C}$ NMR (including DEPT) spectra combined with the HMQC experiment revealed three quaternary carbons (including the olefinic one, at $\delta_{\mathrm{C}} 144.3$, mentioned above), four methine (two of them oxygen-bearing), and four methylene carbons (one olefinic). Compound $\mathbf{3}$ showed no molecular ion peak by HREIMS, although a weak ion fragment at $m / z 221.3279$ $\left[\mathrm{M}-\mathrm{CH}_{3}\right]^{+}(1 \%)$ and an ion fragment at $m / z, 121\left[\mathrm{M}^{+}\right.$- side chain] $(84 \%)$ were observed.

Regarding compound 4, its IR spectrum indicated the presence of hydroxyl groups $\left(3400 \mathrm{~cm}^{-1}\right)$ and a cyclopropane ring $\left(3040 \mathrm{~cm}^{-1}\right)$. Its ${ }^{1} \mathrm{H}$ and ${ }^{13} \mathrm{C}$ (DEPT) NMR spectral data, combined with the HMQC experiment, showed chemical shifts indicative of four signals from methyl groups $\left[\delta_{\mathrm{H}} 0.88,0.99,1.27\right.$, and 1.28 ( $3 \mathrm{H}$ each, s), $\delta_{\mathrm{C}} 17.5$, $10.7,25.6$, and 26.8 , respectively] and also provided evidence of two methine carbinolic carbons $\left[\delta_{\mathrm{H}} 3.24(1 \mathrm{H}, \mathrm{d})\right.$ and $3.86(1 \mathrm{H}, \mathrm{ddd})$, $\delta_{\mathrm{C}} 79.5$ and 72.5, respectively] and another tertiary alcohol $\left[\delta_{\mathrm{C}} 73.6\right]$. Moreover, its ${ }^{1} \mathrm{H}$ NMR and ${ }^{13} \mathrm{C}$ spectra showed signals that could be attributed to a cyclopropane group $\left[\delta_{\mathrm{H}} 0.80(1 \mathrm{H}, \mathrm{dd})\right.$ and $0.84(1 \mathrm{H}$, d), $\delta_{\mathrm{C}} 18.2$ and 19.3, respectively]. Finally, from all the NMR spectral data, evidence was provided of 15 carbon atoms - among them four methyl, three methylene, five methine (including two carbinolic carbons, as mentioned above), and two quaternary groups, besides another oxygen-bearing carbon as tertiary alcohol.

As in the previous compound, no $\left[\mathrm{M}^{+}\right]$peak was seen in the HREIMS of 4, which showed a fragmentation ion peak at $\mathrm{m} / \mathrm{z} 221.1385$ $\left[\mathrm{M}^{+}-\mathrm{H}_{2} \mathrm{O}-\mathrm{CH}_{3}\right](3 \%)$. The combined data from the CIMS $\left(\mathrm{CH}_{4}\right)-$ mass spectra were suggestive of the molecular formula $\mathrm{C}_{15} \mathrm{H}_{26} \mathrm{O}_{3}$.

The IR spectrum of compound $\mathbf{5}$ indicated the presence of one hydroxyl $\left(3250 \mathrm{~cm}^{-1}\right)$, a cyclopropane ring $\left(3019 \mathrm{~cm}^{-1}\right)$, and a band that could be related to the stretching of the C-O-C moiety $\left(1216 \mathrm{~cm}^{-1}\right)$.

Although no $\left[\mathrm{M}^{+}\right]$peak was seen in the GC-EIMS of $\mathbf{5}$, a fragment ion peak was observed at $\mathrm{m} / \mathrm{z}, 121(45 \%)$.

Data obtained from the ${ }^{1} \mathrm{H}$ and ${ }^{13} \mathrm{C}$ (DEPT) NMR spectral data, combined with the HMQC experiment, for $\mathbf{5}$ were found to be very close to those of $\mathbf{4}$. They showed chemical shifts indicative of four signals from methyl groups $\left[\delta_{\mathrm{H}} 0.85,0.99,1.33\right.$, and 1.35 ( $3 \mathrm{H}$ each, s), $\delta_{c} 18.0,10.6,29.0$ and 21.3, respectively], in addition provided evidence of two oxygen-bearing methine carbons $\left[\delta_{\mathrm{H}} 4.36(1 \mathrm{H}, \mathrm{dd})\right.$ and $3.92(1 \mathrm{H}, \mathrm{t}), \delta_{\mathrm{C}} 83.1$ and 78.3 , respectively]. These features are compatible with a sesquiterpene with four methyl groups and three carbons attached to oxygens $\left(\mathrm{C}_{9}, \mathrm{C}_{10}\right.$ and $\left.\mathrm{C}_{11}\right)$. A major difference between both compounds was the chemical shifts of $\mathrm{C}_{9}$ and $\mathrm{C}_{11}$, which in compound 5 were shifted downfield, as compared to 4 (see Table 2), being indicative of the presence of a four-member epoxy group ${ }^{5,6}$, while $\mathrm{C}_{10}$ was assigned to a carbon-bearing $\mathrm{OH}$ group. The presence of the epoxy ring justified the large chemical shift differences observed in the carbons of the methyl groups of the side chain, since they are fixed by this ring. In addition, the presence of only one alcohol hydroxyl was confirmed, in $\mathrm{C}_{10}$, by obtaining the monoacethylated derivative. Another evidence is the multiplicity of $\mathrm{H}_{10}\left(\delta_{\mathrm{H}}\right.$ $3.92, \mathrm{t})$, a feature compatible with the coupling of a vicinal hydrogen $\left(\mathrm{H}_{9}\right)$ and the hydrogen of the hydroxyl alcohol $\left(\mathrm{OH}\right.$ in $\mathrm{C}_{10}, \delta_{\mathrm{H}} 2.02$, d). This fact results from intramolecular hydrogen bonding, with the formation of another ring of five members. The homonuclear correlation between $\mathrm{H}_{10}-\mathrm{H}\left(\mathrm{OH}\right.$ in $\left.\mathrm{C}_{10}\right)$ was confirmed in the ${ }^{1} \mathrm{H}-{ }^{1} \mathrm{H}$ COSY experiment. With the addition of $\mathrm{D}_{2} \mathrm{O}, \mathrm{H}_{10}$ degenerated in a doublet, and the disappearance of the doublet assigned to the alcohol proton, at $\delta_{\mathrm{H}} 2.02(\mathrm{~d})$, was observed.

In order to propose the relative configuration of the 9,10 portion of $\mathbf{2}, \mathbf{3}$, and $\mathbf{4}$, the ring-opening of the epoxide in $\mathbf{2}$ was promoted, and the derivatives 9,10 acetonide, from 3 (3a), and 9,10-, 10,11-, and 9,11-acetonides, from $\mathbf{4}(\mathbf{4 a}, \mathbf{4 b}$ and $\mathbf{4 c})$, were obtained ${ }^{7}$.

The acid hydrolysis of $\mathbf{2}$ (Scheme 1) yielded $\mathbf{4}$ as its main product (76\%), along with $\mathbf{5}(17 \%)$ and another product identified as $\mathbf{3}(7 \%)$ - all of them confirmed by the resemblance of their spectral data to those previously described. The main product was also confirmed by its $[\alpha]^{25}{ }_{D}$.

The ${ }^{1} \mathrm{H}$ spectrum of $\mathbf{3 a}$ showed two additional signals for the methyl groups $\left[\delta_{\mathrm{H}} 1.33\right.$ and $1.47\left(3 \mathrm{H}\right.$ each, s), $\delta_{\mathrm{C}} 25.2$ and 27.2, respectively] and a quaternary carbon at $\delta_{\mathrm{C}} 107.8$. The correlations between this quaternary carbon and the methyl groups were confirmed by the HMBC experiment.

The same analysis was made for the derivatives of compound 4. The ${ }^{1} \mathrm{H}$ NMR spectrum of $\mathbf{4 a}$ showed two additional signals for the methyl groups $\left[\delta_{\mathrm{H}} 1.32\right.$ and $1.46\left(3 \mathrm{H}\right.$ each, s), $\delta_{\mathrm{C}} 25.6$ and 27.8 , respectively], and their ${ }^{13} \mathrm{C}$ NMR spectrum also revealed the presence of one additional signal for the quaternary carbon, at $\delta_{C} 106.9$. The HMBC experiment confirmed the connectivity between the quaternary carbon of the dioxolane ring and those methyl groups. The same correlations from the HMBC experiments were also observed for the methyl groups of $\mathbf{4 b}\left[\delta_{\mathrm{H}} 1.31\right.$ and 1.38 ( $3 \mathrm{H}$ each, $\mathrm{s}$ ), $\delta_{\mathrm{C}} 27.0$ and 28.6, respectively], with $\delta_{\mathrm{C}} 106.6$, and $\mathbf{4 c}\left[\delta_{\mathrm{H}} 1.31\right.$ and 1.44 (3H each, s), $\delta_{\mathrm{C}} 31.7$ and 24.7, respectively], with $\delta_{\mathrm{C}} 98.2$.

The presence of two widely separated additional singlet peaks, in the ${ }^{1} \mathrm{H}$ spectrum of the 9,10-acetonide derivatives from $\mathbf{3}$ and $\mathbf{4}$, as mentioned above $\left[\delta_{\mathrm{H}} 1.33\right.$ and 1.47 for $\mathbf{3 a}$ and $\delta_{\mathrm{H}} 1.32$ and 1.46 for 4a $(3 \mathrm{H}$, each)], both assigned to acetonyl methyl groups, suggested a cis configuration for the dioxolane ring. Thus, erythro is the configuration expected for the 9,10 portions of $\mathbf{3}$ and $\mathbf{4}$, since the $\Delta \delta$ value for the acetonide derivative of the threo isomer is small ${ }^{7}$.

The ring-opening of the epoxide in $\mathbf{2}$ proved to proceed selectively, yielding $4(76 \%)$ as the main product, by $\mathrm{S}_{\mathrm{N}} 1$, in addition to two by-products: $\mathbf{3}$, by $\mathrm{E}_{1}$, and $\mathbf{5}$, by $\mathrm{S}_{\mathrm{N}} \mathrm{i}$. It was possible, based on the evidence of mechanism preference, to propose $\mathbf{2}$ as an erythro isomer, since it yielded only one triol (Scheme 1).

Therefore, the relative configurations of $\mathrm{C}_{9}$ and $\mathrm{C}_{10}$ of $\mathbf{2 , 3}$, and 4 could be considered as being $9 R^{*}, 10 R^{*} ; 9 R^{*}, 10 S^{*}$; and $9 R^{*}, 10 R^{*}$, respectively.

The occurrence of santalane-type sesquiterpenes obtained as artifacts during the extraction process or storage period had already been investigated. Several derivatives from $\alpha$-santalene had previously 
Table 1. ${ }^{1} \mathrm{H}$ spectral data of $\mathbf{1 , 2}, \mathbf{3}, \mathbf{4}$, and $\mathbf{5}\left(300 \mathrm{MHz}, \mathrm{CDCl}_{3}\right)$

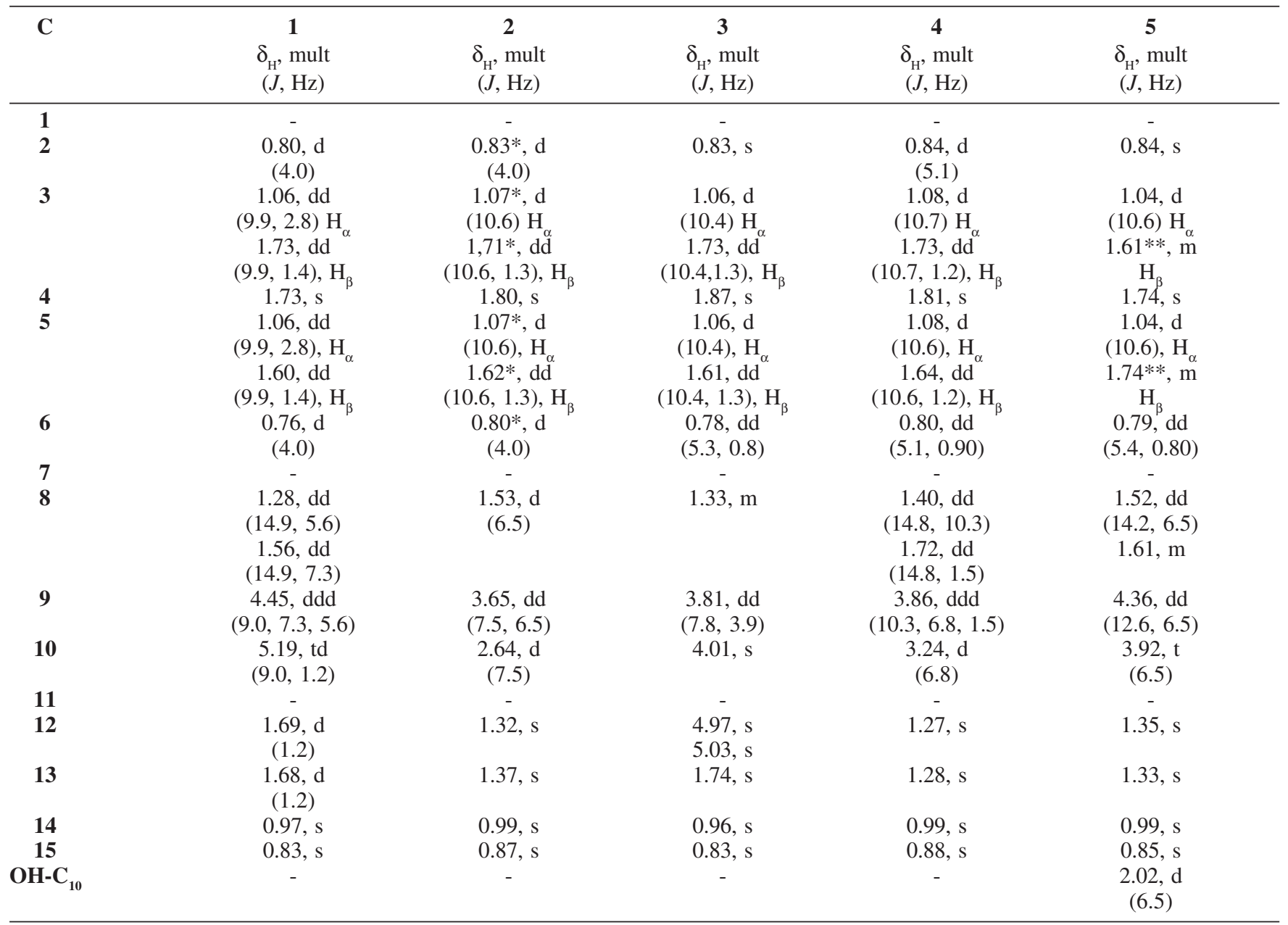

*Assigments made according to the ${ }^{1} \mathrm{H}-{ }^{1} \mathrm{H}$ NOESY experiment.**Assignments interchangeable within column.

Table 2. ${ }^{13} \mathrm{C}$ spectral data of $\mathbf{1 , 2}, \mathbf{3}, \mathbf{4}$, and $\mathbf{5}\left(75 \mathrm{MHz}, \mathrm{CDCl}_{3}\right)$

\begin{tabular}{lccccc}
\hline \multicolumn{1}{c}{$\mathbf{C}$} & $\mathbf{1}$ & $\mathbf{2}$ & $\mathbf{3}$ & $\mathbf{4}$ & $\mathbf{5}$ \\
$(\mathrm{DEPT})$ & \multicolumn{1}{c}{$\boldsymbol{\delta}_{\mathrm{C}}$} & $\boldsymbol{\delta}_{\mathrm{C}}$ & $\boldsymbol{\delta}_{\mathrm{C}}$ & $\boldsymbol{\delta}_{\mathrm{C}}$ & $\boldsymbol{\delta}_{\mathrm{C}}$ \\
\hline $1(\mathrm{C})$ & 27.8 & 27.4 & 27.1 & 27.0 & 27.3 \\
$2(\mathrm{CH})$ & 19.5 & $19.4^{*}$ & 19.4 & 19.3 & 19.4 \\
$3\left(\mathrm{CH}_{2}\right)$ & 31.3 & $31.3^{*}$ & 31.4 & 31.3 & 31.2 \\
$4(\mathrm{CH})$ & 39.3 & 39.5 & 39.5 & 39.5 & 39.1 \\
$5\left(\mathrm{CH}_{2}\right)$ & 31.6 & $31.6^{*}$ & 31.5 & 31.6 & 31.4 \\
$6(\mathrm{CH})$ & 18.7 & $18.9 *$ & 18.4 & 18.2 & 18.9 \\
$7(\mathrm{C})$ & 44.8 & 44.9 & 44.9 & 45.2 & 44.7 \\
$8\left(\mathrm{CH}_{2}\right)$ & 41.7 & 38.8 & 34.2 & 37.3 & 40.4 \\
$9\left(\mathrm{CH}^{2}\right.$ & 66.8 & 68.4 & 70.7 & 72.5 & 83.1 \\
$10\left(\mathrm{CH}^{2}\right)$ & 129.7 & 66.7 & 79.4 & 79.5 & 78.3 \\
$11(\mathrm{C})$ & 133.5 & 59.4 & 144.3 & 73.6 & 84.9 \\
$12\left(\mathrm{CH}_{3}\right)$ & 25.8 & 25.0 & 112.8 & 25.6 & 21.3 \\
$13\left(\mathrm{CH}_{3}\right)$ & 18.1 & 18.5 & 19.1 & 26.8 & 29.0 \\
$14\left(\mathrm{CH}_{3}\right)$ & 10.7 & 10.6 & 10.7 & 10.7 & 10.6 \\
$15\left(\mathrm{CH}_{3}\right)$ & 18.1 & 17.7 & 17.6 & 17.5 & 18.0 \\
\hline
\end{tabular}

*Assignments made according to ${ }^{1} \mathrm{H}-{ }^{1} \mathrm{H}$ NOESY combined with HMQC experiments.

been reported to occur as natural products, although they could also have been obtained as artifacts after long periods under ambient conditions. Autoxidation reactions might also have occurred in the plant cells, indeed ${ }^{4}$.
In the present work, the sesquiterpenes $\mathbf{3 , 4}$, and $\mathbf{5}$ might be artifact products obtained during the extraction and purification of $\mathbf{2}$, since they were acid hydrolysis products of this compound. In order to verify this possibility, compound 2 was shaken for 48 hours with silica gel plus the solvent employed for CC elution and monitored by TLC (as described in the experimental part), but no reaction whatsoever was observed.

Another fact that deserves attention is the oxygenation pattern of the santalane sequiterpene side-chain here described, which has an additional hydroxyl group in C-9, unlike those described in the literature ${ }^{3,4}$.

Regarding polycarpol, its spectral data were compared to the literature ${ }^{8}$. Although previously obtained from another species of the Annonaceae family, its isolation is here being described for the first time in the Duguetia genus, and it has been suggested as a chemotaxonomic marker for this family ${ }^{8}$.

\section{EXPERIMENTAL PART}

\section{General experimental procedures}

Mp was determined on a Uniscience 498 apparatus and is uncorrected. Optical rotation was run in chloroform on a PerkinElmer 341. The FT-IR spectrum was measured as a $\mathrm{KBr}$ pellet or $\mathrm{CHCl}_{3}$ film on a Perkin Elmer 783. The High Resolution Electron 

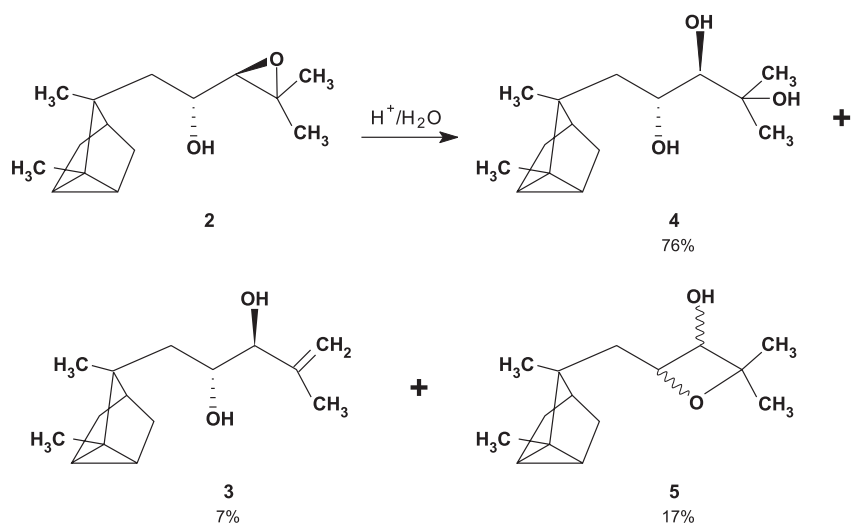

Scheme 1. Hydrolysis of compound 2, yielding 4, 3, and 5

Impact Mass Spectra (HREIMS) were recorded on a V.G. Auto Espec. EBE instrument; the GC-EIMS was obtained on a CG17A/QP 5000 Shimadzu GC/MS instrument. All NMR experiments were performed on a Brucker DPX-300 instrument $\left({ }^{1} \mathrm{H}: 300 \mathrm{MHz} ;{ }^{13} \mathrm{C} 75 \mathrm{MHz}\right)$ using $\mathrm{CDCl}_{3}$ as a solvent and TMS as an internal standard. Chemical shifts are reported in $\delta$ units and coupling constants $(J)$ in $\mathrm{Hz} .60 \mathrm{G}$ and 60 $\mathrm{GF}_{254}$ silica gel (Merck) and 70-230 mesh (Aldrich) were used for TLC and CC, respectively.

\section{Plant material}

The stem bark of Duguetia glabriuscula R. E. Fr. (R. E. Fr.) was collected in the municipality of Jardim, MS, Brazil and identified by Prof. R. Mello Silva. A voucher specimen (number 4769) has been deposited in the UFMS Herbarium (Campo Grande, MS).

\section{Extraction and isolation of compounds}

The air-dried, powdered stem bark of D. glabriuscula $(380 \mathrm{~g})$ was submitted to exhaustive petroleum ether extraction in a soxhlet apparatus. The resulting extract was concentrated in vacuo to dryness ( $15 \mathrm{~g}$ ), and 6 $\mathrm{g}$ of it were then submitted to silica gel column chromatography ( $350 \mathrm{~g})$ using petroleum ether: hexane, hexane, hexane: ethyl acetate, and ethyl acetate as the gradient for elution. The following compounds were thus purified: 1 (45 mg, isolated from hexane: ethyl acetate, 96:4), 2 (178 mg, hexane: ethyl acetate, 90:10), $\mathbf{3}$ (15.8 $\mathrm{mg}$, hexane: ethyl acetate, 85:15), 4 (202 mg, hexane: ethyl acetate, 65:35), 5 (26.5 mg, by preparative TLC, dichloromethane :methanol 96:4) and polycarpol (5.7 $\mathrm{mg}$, after purification by preparative TLC).

\section{Identification of isolated compounds}

(+)- $\alpha$-santal-10-en-9-ol (1), 1-(2,3-dimethyltricyclo[2.2.1.0 $\left.0^{2,6}\right]$ hept-3-yl)-4-methylpent-3-en-2-ol: $\mathrm{C}_{15} \mathrm{H}_{24} \mathrm{O}$, oil, $[\alpha]_{\mathrm{D}}^{25}:+3.19^{\circ}\left(\mathrm{CHCl}_{3}\right.$, c 0.01); FT-IR $v_{\max } / \mathrm{cm}^{-1}: 3373,3050,2934,2845,1676,1456,1369$ $\left(\mathrm{CHCl}_{3}\right) ;{ }^{13} \mathrm{C} \mathrm{NMR}\left(\mathrm{CDCl}_{3}, 75 \mathrm{MHz}\right)$ : Table $2 ;{ }^{1} \mathrm{H} \mathrm{NMR}\left(\mathrm{CDCl}_{3}, 300\right.$ $\mathrm{MHz}$ ): Table 1. HREIMS: $m / z$ (rel. int.) found $220.1819\left[\mathrm{M}^{+}, \mathrm{C}_{15} \mathrm{H}_{24} \mathrm{O}\right.$, requires 220.1828] (35), 121 [M+ - side-chain](17), 57(100).

(+)- $\alpha$-santalan-10,11-epoxy-9-ol (2), 1-(3,3-dimethyloxiran-2yl)-2-(2,3-dimethyltricyclo[2.2.1.0 $\left.0^{2,6}\right]$ hept-3yl-ethanol: oil, $[\alpha]_{\mathrm{D}}^{25}:+$ $17.7^{\circ}\left(\mathrm{CHCl}_{3}, c 0.02\right)$; FT-IR $v_{\max } / \mathrm{cm}^{-1}: 3443,3050,2963,2874,1713$, $1455,1379,1100,1085\left(\mathrm{CHCl}_{3}\right) ;{ }^{13} \mathrm{C} \mathrm{NMR}\left(\mathrm{CDCl}_{3}, 75 \mathrm{MHz}\right)$ : Table 2; ${ }^{1} \mathrm{H}$ NMR $\left(\mathrm{CDCl}_{3}, 300 \mathrm{MHz}\right)$ : Table 1. HREIMS: $\mathrm{m} / z$ (rel. int.) 236.1771[ $\mathrm{M}^{+}, \mathrm{C}_{15} \mathrm{H}_{24} \mathrm{O}_{2}$, requires 236.1777] (16), $221\left[\mathrm{M}^{+}-\mathrm{CH}_{3}\right](10)$, $121\left[\mathrm{M}^{+}\right.$- side-chain](100), 105(28), 72(93).

$\alpha$-Santal-11-en-9,10-diol (3), 1-(2,3-dimethyltricyclo[2.2.1.0 $\left.0^{2,6}\right]$ hept-3-yl)-4-methylpent-4-ene-2,3-diol: oil, FT-IR $v_{\max } / \mathrm{cm}^{-1}: 3410$, 3051, 2945, 2865, 1719, 1451, $898\left(\mathrm{CHCl}_{3}\right) ;{ }^{13} \mathrm{C} \mathrm{NMR}\left(\mathrm{CDCl}_{3}, 75\right.$ $\mathrm{MHz})$ : Table 2; ${ }^{1} \mathrm{H}$ NMR $\left(\mathrm{CDCl}_{3}, 300 \mathrm{MHz}\right)$ : Table 1. HREIMS: $\mathrm{m} / \mathrm{z}$ (rel. int.) $221.3258\left[\mathrm{M}^{+}-\mathrm{CH}_{3}, \mathrm{C}_{14} \mathrm{H}_{21} \mathrm{O}_{2}\right.$, requires 221.1542](1), 165(34), 121(84), 72(100).

(+)- $\alpha$-santalan-9,10,11-triol (4), 1-(2,3-dimethyltricyclo [2.2.1.0 2,6]hept-3-yl)-4-methylpentane-2,3,4-trio: colorless crystal $\left(\mathrm{CHCl}_{3}\right), \mathrm{mp} 110-112^{\circ} \mathrm{C},[\alpha]^{25} \mathrm{D}:+30,0^{\circ}\left(\mathrm{CHCl}_{3}, c 0.05\right)$; FT-IR $v_{\max } / \mathrm{cm}^{-1}: 3400,3040,2920,1170,1080,990,900(\mathrm{KBr}) ;{ }^{13} \mathrm{C} \mathrm{NMR}$ $\left(\mathrm{CDCl}_{3}, 75 \mathrm{MHz}\right)$ : Table 2; ${ }^{1} \mathrm{H} \mathrm{NMR}\left(\mathrm{CDCl}_{3}, 300 \mathrm{MHz}\right)$ : Table 1. HREIMS: $m / z$ (rel. int.) $221.1385\left[\mathrm{M}^{+}-\mathrm{CH}_{3}-\mathrm{H}_{2} \mathrm{O}, \mathrm{C}_{14} \mathrm{H}_{21} \mathrm{O}_{2}\right.$, requires 221.1018](3), 121(100); CIMS 271[M + $\left.\mathrm{H}+\mathrm{CH}_{4}\right]^{+}(1)$.

(+)- $\alpha$-santalan-9,11-epoxy-10-ol (5), 4-[(2,3-dimethyltricyclo [2.2.1.0 2,6]hept-3-yl)methyl]-2,2-dimethyloxetan-3-ol: oil, $[\alpha]_{\mathrm{D}}^{25}:+4.7^{\circ}\left(\mathrm{CHCl}_{3}, c 0.02\right)$, FT-IR $v_{\max } / \mathrm{cm}^{-1}: 3250,3019,2921,2849$, 1719, 1459, $1216\left(\mathrm{CHCl}_{3}\right) \cdot{ }^{13} \mathrm{C} \mathrm{NMR}\left(\mathrm{CDCl}_{3}, 75 \mathrm{MHz}\right)$ : Table $2 ;{ }^{1} \mathrm{H}$ NMR $\left(\mathrm{CDCl}_{3}, 300 \mathrm{MHz}\right)$ : Table 1. GC-EIMS: $\mathrm{m} / z$ (rel. int.) $121\left[\mathrm{M}^{+}\right.$ - side chain, $\left.\mathrm{C}_{9} \mathrm{H}_{13}\right](45), 175(10), 152(8), 93(55), 72(100)$.

Polycarpol, isolated as white amorphous solid. ${ }^{1} \mathrm{H}$ NMR (300 $\mathrm{MHz}, \mathrm{CDCl}_{3}$ ), $\delta: 0.59$ (3H, s, H-18), 0.86 (3H, s, H-28), 0.86 (3H, d, $J=4.4 \mathrm{~Hz}, \mathrm{H}-21), 0.91$ (3H, s, H-30), 0.96 (3H, s, H-19), 0.98 (3H s, H-29), 1.07 (dd, $J=11.6,4.0$ Hz, H-5), 1.21-1.44 (m, H-22), 1.58 (3H, s, H-26), 1.66 (3H, s, H-27), 1.72 (ddd, $J=10.9,6.9,1.6 \mathrm{~Hz}$, H-2), 1.94-1.97 (m), 2.03 (dd, $J=17.8,5.7 \mathrm{~Hz}, \mathrm{H}-12 \mathrm{~b}$ ), 2.11 (dd, $J$ = 6.0, $4.0 \mathrm{~Hz}), 2.27$ (d, $J=17.8 \mathrm{~Hz}, \mathrm{H} 12 \mathrm{a}), 3.22$ ( d, $J=10.9 \mathrm{~Hz}, \mathrm{H}-$ 3), 4.25 ( dd, $J=9.3,5.9 \mathrm{~Hz}, \mathrm{H}-15$ ), 5.06 ( t $J=6.9 \mathrm{~Hz}, \mathrm{H}-24), 5.29$ $(\mathrm{d}, J=5.7 \mathrm{~Hz}, \mathrm{H}-11), 5.83(\mathrm{~d}, J=6.0 \mathrm{~Hz}, \mathrm{H}-7) .{ }^{13} \mathrm{C} \mathrm{NMR}(75 \mathrm{MHz}$, $\mathrm{CDCl}_{3}$ ), $\delta$ : 15.8 (C-18), 28.1 (C-28), 17.1 (C-30), 17.6 (C-26), 18.4 (C-21), 22.8 (C-19), 22.9 (C-6), 24.9 (C-23), 25.7 (C-27), 27.8 (C2), 15.0 (C-29), 35.7 (C-1), 35.8 (C-20), 36.2 (C-22), 37.4 (C-10), 38.5 (C-12), 38.7 (C-4), 40.1 (C-16), 44.3 (C-13), 48.9 (C-5), 48.9 (C-17), 51.9 (C-14), 74.7 (C-15), 78.9 (C-3), 116.1 (C-11), 121.3 (C-7), 124.9 (C-24), 131.2 (C-25), 140.9 (C-8), 146.1 (C-9)

\section{Opening of the epoxide ring in 2}

$43 \mathrm{mg}$ of 2 were solubilized with $11 \mathrm{~mL}$ of dried acetone and 15 $\mathrm{mL}$ of distilled $\mathrm{H}_{2} \mathrm{O}$, and drops of glacial acetic acid were added until $\mathrm{pH} 5$ was reached, under agitation. The reaction was maintained at room temperature for $24 \mathrm{~h}$, and monitored by TLC $\left[\left(\mathrm{CHCl}_{3}: \mathrm{MeOH}\right.\right.$ $1 \%$, developed with $\left.\mathrm{Ce}\left(\mathrm{SO}_{4}\right)_{2}\right)$ ], using as a pattern an authentic sample of the (+)- $\alpha$-santalan-9,10,11-triol, 4 . After that period, the whole departure material had been consumed, and the analysis by means of TLC, followed by ${ }^{1} \mathrm{H},{ }^{13} \mathrm{C}$ NMR (including DEPT) spectral data and $[\alpha]_{D}^{25}$, indicated that the main product obtained was $4(76 \%)$, in addition to $5(17 \%)$ and $\mathbf{1}(7 \%)$.

Preparation of the acetonide 9,10-isopropylidene- $\alpha$-santal-11en (3a) from 3

Compound 3 (7 mg) was dissolved in dried acetone $(7 \mathrm{~mL})$ with traces of $p$-toluenesulfonic acid. The mixture was maintained at room temperature and monitored by TLC. After 6 hours, 3 had been completely consumed. The reaction mixture was then concentrated, added $\mathrm{CHCl}_{3}$, and filtered. The organic phase was submitted to preparative TLC and 3a was confirmed (silica gel G60, Merck, 0.7mm layer, eluent $\mathrm{CHCl}_{3}$, Rf of 3: 0.2, Rf of 3a: 0.9).

\section{9,10-isopropylidene- $\alpha$-santal-11-em (3a)}

Oil, ${ }^{1} \mathrm{H}$ NMR spectrum of 3a (300 MHz, $\left.\mathrm{CDCl}_{3}\right), \delta: 0.77$ (d, 5.1 $\mathrm{Hz}), 0.82$ (s), $0.82(3 \mathrm{H}, \mathrm{s}), 0.95(3 \mathrm{H}, \mathrm{s}), 1.03(2 \mathrm{H}, \mathrm{d}, J=9.6 \mathrm{~Hz}), 1.70$ (s), $1.70(3 \mathrm{H}, \mathrm{s}), 1.84$ (s), 1.62 (d, $9.6 \mathrm{~Hz}), 1.33$ (2H, s), 4.28 (ddd, 
9.9; 6.8. 2.1 Hz), 4.47 (d, $6.8 \mathrm{~Hz}), 4.92$ (s), 4.94 (s), 1.33 (3H, s), $1.47(3 \mathrm{H}, \mathrm{s}) .{ }^{13} \mathrm{C}$ NMR spectrum $\left(75 \mathrm{MHz}, \mathrm{CDCl}_{3}\right)$ of $\mathbf{3 a}, \delta: 10.7$, $17.4,18.8,19.5,19.8,27.0,31.3,31.4,33.2,39.4,45.2,75.6,82.2$, 142.4, 113.0, 107.8 (acetal carbon), 25.2 (acetal methyl group), 27.2 (acetal methyl group).

Preparation of 9,10-isopropylidene- $\alpha$-santalan-11-ol (4a), 10,11isopropylidene- $\alpha$-santalan-9-ol (4b), and 9,11-isopropylidene- $\alpha$ santalan-10-ol (4c) - the acetonides derivatives from 4

Compound 4 (10 mg) was dissolved in dried acetone $(5 \mathrm{~mL})$ with traces of $p$-toluenesulfonic acid. The mixture was maintained for $2 \mathrm{~h}$ at room temperature, being monitored by TLC. As no development of the reaction was observed after that period, extra traces of acid were added, so that $\mathbf{4}$ was completely consumed in a total time of $5.5 \mathrm{~h}$. The reaction mixture was then concentrated, added $\mathrm{CHCl}_{3}$, and filtered. The organic phase was submitted to preparative TLC (silica gel G60, Merck, 0.7-mm layer, eluent $\mathrm{CHCl}_{3}$ ). After running time, the plate edge was developed with anisaldehyde and three violet spots were made visible. The usual workup was employed to obtain 4a (Rf 0.37, $2.1 \mathrm{mg}), \mathbf{4 b}(\operatorname{Rf} 0.32,1.6 \mathrm{mg})$, and $\mathbf{4 c}(\mathrm{Rf}$ $0.26,3.1 \mathrm{mg})$.

\section{9,10-isopropylidene- $\alpha$-santalan-11-ol}

Oil, ${ }^{1} \mathrm{H}$ NMR spectra of $\mathbf{4 a}\left(300 \mathrm{MHz}, \mathrm{CDCl}_{3}\right), \delta: 0.78$ (dd, 6.0, $0.9 \mathrm{~Hz}), 0.85(3 \mathrm{H}, \mathrm{s}), 0.85$ (s), 0.98(3H, s), 1.07 (m), $1.24(3 \mathrm{H}, \mathrm{s})$, $1.26(3 \mathrm{H}, \mathrm{s}), 1.73$ (dd, 10.6, 1.1 Hz), 1.81 (s), 3.80 (d, $6.1 \mathrm{~Hz}), 4.24$ (ddd, 10.6, 6.1, 3.3 Hz), , 1.32 (s, acetal methyl group), 1.46 (s, acetal methyl group). ${ }^{13} \mathrm{C}$ NMR spectrum $\left(75 \mathrm{MHz} \mathrm{CDCl}_{3}\right)$ of $\mathbf{4 a}, \delta$ : 10.8, 17.3, 18.7, 19.5, 25.6, 27.1, 28.2, 31.3, , 31.5, 33.4, 39.7, 45.6, 83.9, 75.6, 71.1, 106.9 (acetal carbon), 25.6 (acetal methyl group), 27.8 (acetal methyl group). GC-EIMS: $m / z$ (rel. int.) $294\left[\mathrm{M}^{+}\right](<1)$, $279\left[\mathrm{M}^{+}-\mathrm{CH}_{3}\right](2), 164(13), 121\left[\mathrm{M}^{+}\right.$- side chain $](77), 59(100)$.

\section{0,11-isopropylidene- $\alpha$-santalan-9-ol}

Oil, ${ }^{1} \mathrm{H}$ NMR spectra of $\mathbf{4 b}\left(300 \mathrm{MHz}, \mathrm{CDCl}_{3}\right), \delta: 0.80(\mathrm{~d}, 6.0$ Hz), 0.85 (dd, 6.0, $1.0 \mathrm{~Hz}$ ), 1.09 ( d, 10.7), 1.64 (d, 10.5, $1.4 \mathrm{~Hz}$ ), 1.74 (d, $1.3 \mathrm{~Hz}), 1.81$ ( s), 3.82 (t, $8.3 \mathrm{~Hz}), 3.43$ (m), $1.23(3 \mathrm{H}, \mathrm{s})$, $1.34(3 \mathrm{H}, \mathrm{s}), 1.09(3 \mathrm{H}, \mathrm{s}), 0.89(3 \mathrm{H}, \mathrm{s}), 1.31$ '(s, acetal methyl group), 1.38 's, acetal methyl group). ${ }^{13} \mathrm{C}$ NMR spectra of $\mathbf{4 b}(75 \mathrm{MHz}$, $\left.\mathrm{CDCl}_{3}\right), \delta: 10.8,17.5,18.1,19.4,23.2,27.0,28.0,31.4,31.7,38.5$, 39.8, 45.2, 69.4, 85.4, 80.7, 106.6 (acetal carbon), 27.0 (acetal methyl group), 28.6 (acetal methyl group). GC-EIMS $\mathrm{m} / \mathrm{z}$ (rel. int.): 294 $\left[\mathrm{M}^{+}\right]$(not observed), $279\left[\mathrm{M}^{+}-\mathrm{CH}_{3}\right]$ (2), 164(12), 121(29), 59(100).

\section{9,11-isopropylidene- $\alpha$-santalan-10-ol}

Oil, ${ }^{1} \mathrm{H}$ NMR spectra of $\mathbf{4 c}\left(300 \mathrm{MHz}, \mathrm{CDCl}_{3}\right), \delta: 0.76(\mathrm{~d}, 5.2$ $\mathrm{Hz}), 0.80$ (d, $5.2 \mathrm{~Hz}), 0.86(3 \mathrm{H}, \mathrm{s}), 0.99(3 \mathrm{H}, \mathrm{s}), 1.06(\mathrm{~m}), 1.28(3 \mathrm{H}$, s), $1.28(3 \mathrm{H}, \mathrm{s}), 1.63(\mathrm{~s}), 1.75(\mathrm{~m}), 1.78(\mathrm{~s}), 3.16(\mathrm{t}, 8.4,5.3 \mathrm{~Hz})$, 3.73 (dt, 8.4, $1.7 \mathrm{~Hz}), 1.31$ (s, acetal methyl group), 1.44 (s, acetal methyl group). ${ }^{13} \mathrm{C}$ NMR spectra of $4 \mathbf{c}\left(75 \mathrm{MHz} \mathrm{CDCl}_{3}\right), \delta: 10.8$,
$17.7,18.6,19.4,23.4,27.0,30.3,31.3,31.4,36.1,39.6,45.2,68.9$, 76.6, 74.8, 98.2 (acetal carbon), 31.7 (acetal methyl group), 24.7 (acetal methyl group). GC-EIMS $\mathrm{m} / \mathrm{z}$ (rel. int.): 294 [M+] (not observed), $279\left[\mathrm{M}^{+}-\mathrm{CH}_{3}\right]$ (2), 164(12), 121(49), 59(100).

\section{Obtaining a monoacethylated derivative of 5}

$14.3 \mathrm{mg}$ of 5 with $1 \mathrm{~mL}$ of acetic anhydride and $1 \mathrm{~mL}$ of pyridine were shaken at room temperature overnight. The disappearance of $\mathbf{5}$ was revealed by TLC. The reactive mixture was submitted to 100 $\mathrm{mL}$ of chloride acid with crushed ice and extracted with $\mathrm{CHCl}_{3}$. The resulting yellow oil was analyzed.

Oil, FT-IR $v_{\max } / \mathrm{cm}^{-1}: 2927,2848,1739,1367,1233,660\left(\mathrm{CHCl}_{3}\right)$; NMR ${ }^{1} \mathrm{H}\left(\mathrm{CDCl}_{3}, 300 \mathrm{MHz}\right), \delta: 0.78(3 \mathrm{H}, \mathrm{s}), 0.80(\mathrm{~d}, J=0.9 \mathrm{~Hz})$, 0.83 (s), $0.99(3 \mathrm{H}, \mathrm{s}), 1.04(2 \mathrm{H}, \mathrm{d}, J=11.1 \mathrm{~Hz}), 1.28(3 \mathrm{H}, \mathrm{s}), 1.42$ $(3 \mathrm{H}, \mathrm{s}), 1.53-1.77(4 \mathrm{H}, \mathrm{m}), 2.08$ (methyl of Ac group, s), $4.53(1 \mathrm{H}$, ddd, $J=7.3,5.3,5.8 \mathrm{~Hz}), 4.69$ ( d, $J=5.8 \mathrm{~Hz}) . \quad \mathrm{NMR}{ }^{13} \mathrm{C}(75 \mathrm{MHz}$, $\left.\mathrm{CDCl}_{3}\right)$, $\delta:$ 10.6, 17.7, 18.7, 19.3, 20.6, 21.9, 27.3, 28.8, 31.3, 31.4, 39.1, 40.2, 44.7, 78.6, 78.8, 83.9, 170.3; GC-EIMS m/z (rel. int.): 175(7), 152(18), 121(52), 105(23), 93(65), 79(22), 72(100), 55(17).

Attempts to obtaining 3, 4, and 5 by opening the epoxy ring in 2 by silica gel catalysis

$20 \mathrm{mg}$ of $\mathbf{2}$ were solubilized in methylene chloride:ethyl acetate, $1: 1$, and shaken at room temperature. After the first $24 \mathrm{~h}$, because no reaction was observed by TLC monitoring, $500 \mathrm{mg}$ of distilled water were added and the mixture was kept under the same conditions. After an additional $24 \mathrm{~h}$, it was possible to confirm only compound $\mathbf{2}$.

\section{ACKNOWLEDGMENTS}

The authors are grateful to Departamento de Química, CCET, of UFMS, for making their facilities available for additional analyses. This work was financially supported by CPq-PROPP-UFMS and FUNDECT-MS-Brazil (process 0117/99).

\section{REFERENCES}

1. Muhammad, I.; Dunbar, D. C.; Takamatsu, S.; Walker, L. A.; Clark, A. M.; J. Nat. Prod. 2001, 64, 559.

2. De Siqueira, J. M.; Boaventura, M. A. D.; Ziminiani, M. G.; Resende, U. M.; Quim. Nova 2001, 24, 185.

3. Ngo, K-S.; Brown, G. D.; Phytochemistry 1999, 50, 1213; Morris, D. G.; Murray, A. M.; J. Chem. Soc., Perkin Trans. 2 1975, 2, 734; Wu, T-S.; Niwa, M.; Furukawa, H.; Phytochemistry 1984, 23, 595.

4. Ngo, K-S; Brown, G. D.; J. Chem. Res., Synop. 2000, 68.

5. Kalinowski, H-O.; Berger, S.; Braun, S.; Carbon-13 NMR Spectroscopy, $2^{\text {nd }}$ ed., Willey \& Sons: New York, 1988

6. Silverstein, R. M.; Bassler, G. C.; Morrill, T. C.; Identificação Espectrométrica de Composto Orgânicos, $5^{\mathrm{a}}$ ed., Guanabara Koogan: Rio de Janeiro, 1997, p. 162-167.

7. Colman-Saizarbitoria, T.; Alfonso, D.; McLaughlin, J. L.; Phytochem. Anal. 1996, 7, 313; Da Silva, E. L. M.; Roblot, F.; Mahuteau, J.; Cavé, A.; J. Nat. Prod. 1996, 59, 528.

8. Jung, J. H.; Pummangura, S.; Chaichantipyuth, C.; Patarapanich, C.; McLaughlin, J. L.; Phytochemistry 1990, 29, 1667. 